\title{
Health effects among COVID-19 frontline health care professionals using level III personal protective equipment: A hospital-based descriptive study
}

\author{
Bindu $\mathrm{CM}^{1}$, Reena $\mathrm{R}^{2}$, Shyam AC ${ }^{3}$, Vivek ${ }^{4}$, Chandrakala $\mathrm{C}^{5}$, Usha SMR \\ ${ }^{1}$ Professor, ${ }^{2}$ Associate Professor, ${ }^{6}$ Professor and Head, Department of Biochemistry, ${ }^{3}$ Professor, ${ }^{5}$ Statistician/Tutor, \\ Department of Community Medicine, ${ }^{4}$ Assistant Professor, Department of Respiratory Medicine, Rajarajeswari Medical \\ College and Hospital, Bengaluru, Karnataka, India
}

\section{A B S T R A C T}

Background: Global outbreak of deadly Corona virus disease has forced health care professionals of various disciplines in Hospital and community setting to use personal protective equipment (PPE) which consists of completely encapsulated suit, led the frontline health care professionals to face not only the physical discomfort but also other health consequences. Aims and Objectives: This study is conducted to assess the physical, physiological, and psychological health consequences faced by health care workers using Level III PPE when attending COVID-19 patients. Materials and Methods: This is a crosssectional study conducted in the month of December 2020 and January 2021 amongst Medicos, Paramedicals, Nurses and other health care professionals in a tertiary care hospital attending COVID-19 duty using an online questionnaire which included sociodemographic profile, frequency of the duty, physical, physiological, psychological difficulties faced while using PPE, and the responses was recorded according to three-point Likert's scale. Data were analyzed using suitable statistical methods with the help of SPSS V.23. Results: A total of 227 front line warriors were included in the study with 157 (69\%) males, $70(31 \%)$ females among them $121(53 \%)$ medicos, 68 (30\%) nurses, 23 (10\%) paramedicals, 15 (7\%) others. Majority of them that is 186 were in 21-30 years age group, 31 in 31-40 years, 10 in $>41$ years. $124(55 \%)$ used PPE for $4-6 h, 84(37 \%)>6 h$ and $19(8 \%)$ used for $<4 \mathrm{~h}$. Physical symptoms are most commonly faced health consequences followed by psychological and physiological symptoms. Medicos faced more difficulty and regularly in all three health consequences comparing with nurses and others. Conclusion: This study provides insight into various health consequences and difficulties experienced by the health care professionals while on PPE. Surveillance of the physical, physiological and psychological health consequences enroute us to prepare efficiently for future outbreaks worldwide.

\section{Access this article online}

Website:

http://nepjol.info/index.php/AJMS DOI: 10.3126/ajms.v13i2.40795

E-ISSN: 2091-0576

P-ISSN: 2467-9100

Copyright (c) 2022 Asian Journal of Medical Sciences

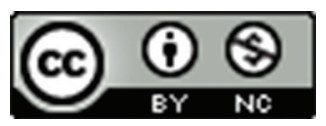

This work is licensed under a Creative Commons Attribution-NonCommercial 4.0 International License.

Key words: Personal protective equipment; Health care professionals; COVID-19

\section{INTRODUCTION}

First case of novel corona virus disease (COVID-19) was reported on $8^{\text {th }}$ of December 2019 in China, which later evolved into a global pandemic, finally affecting 218 counties and territories around the world including India. ${ }^{1}$ The World Health Organization declared COVID-19 a pandemic and declared it a public health emergency of international concern and named it as novel coronavirus disease 2019. ${ }^{2}$ This unexpected life threatening acute respiratory disease resulted devastation in the field of Medicine all over the world.

The outbreak which started in Hubei and Wuhan cities of China, spread across the rest of the country and to other countries too within a short period of time. ${ }^{3}$ India reported 
first case of COVID-19 in Kerala on $30^{\text {th }}$ January 2020 and within a couple of weeks it spread to 27 states and 7 union territories. Since the initial outbreak, health care professionals have faced risk of contracting the virus through contact with infected individuals or contaminated surfaces. All COVID-19 affected countries in the world are implementing containment interposition and trying their level best to fight against disease to halt further spread of infection and to reduce mortality. The major route of transmission of COVID-19 is through respiratory droplets, close contact and as well as via aerosol transmission. ${ }^{4}$ This critical situation of global outbreak forced the health care professionals of various disciplines to use personal protective equipment (PPE), which act as effective barrier between frontline warriors and contaminated material such as blood, body fluids, respiratory secretions, and aerosols while treating COVID-19 patients to avoid contracting the infection. ${ }^{5}$ In light of this pandemic, the importance of use of PPE that includes a disposable medical N95 protective mask, goggles, triple layers of medical gloves, a protective face shield, an isolation gown, and medical protective clothing in health institutions has become more important and critical than it was previously and it should be used consistently and effectively. ${ }^{6}$ Usage of this PPE led the health care professionals to face not only the physical discomfort but also physiological and psychological health consequences.

All over the world extensive studies were conducted on various aspects of COVID-19 caused by corona virus infection. Studies were also carried out to assess the various health challenges faced by health care professionals while using PPE. ${ }^{6-8}$ Globally, the users have often found wearing PPE were uncomfortable while working especially in summer season when facilities like centralized air conditioners were shut down due to fear of spreading of infection and users also found impaired visibility, difficulty in communication, heat stress, respiratory difficulties, nausea, vomiting, sweating, and skin injuries. ${ }^{8-11}$

Based on our literature search, the study which comprehensively uncovers the potential physical physiological and psychological problems with the usage of PPE in an Indian scenario was not found. The comfort of these COVID-19 frontline warriors is utmost importance to execute medical actions including life-saving procedures. Thus, there is an immediate need to unravel these health hazards in health care workers. Hence, this study is conducted to understand the health consequences among the health care workers using PPE, which helps to plan necessary proactive measures for the wellbeing and efficient performance of health care personnel.

\section{Aims and objectives}

The study aims to explore physical, physiological, and psychological health consequences among health care professionals using Level III PPE while treating COVID-19 patients.

\section{MATERIALS AND METHODS}

This is a cross-sectional study, conducted amongst health care professionals in a tertiary Care Hospital. Study was carried out in the month of December 2020 and January 2021. A total of 227 health care professionals which includes Medicos, Paramedicals, Nurses, and other health care related personnel (attenders) posted for COVID-19 duties and who worked for less than $4 \mathrm{~h}, 4-6 \mathrm{~h}$ and more than $6 \mathrm{~h}$ in a day using Level III PPE were included.

The study was pre-approved by the Institutional Ethics Committee (IEC) for the final permission. After obtaining ethical clearance from IEC, an online informed consent was taken from all the participants. Online questionnaire was designed on Google forms and to those who accepted to be a part of the study the form was circulated in WhatsApp group. The submission form was kept open for 30 days. This platform ensured only one submission from one individual. In the WhatsApp, participants received general information about the study and were also informed that their participation is completely voluntary, no personal data are required, study did not have any risk, their data and participation shall be kept anonymous.

Questionnaire included sociodemographic profile, frequency of the duty, various physical, physiological, and psychological health consequences faced while using PPE. To assess the physical, physiological, and psychological problems while using PPE five, seven, and fourteen questions (Tables 1-3) were used, respectively. The responses of the survey were recorded according to three-point Likert's scale. Each question of physical status was assessed to know the difficulty level, hence in the questionnaire participants had to select whether the particular physical problem they faced while wearing the PPE was very difficult, difficult or not at all difficult. In contrary, participants had to select whether particular physiological and psychological problem were faced occasionally, regularly or not all. Validation of data, preliminary analysis, data categorization, and graphical representation was done.

\section{Statistical analysis}

Data were entered in MS excel sheet and were analyzed to find frequency and percentages using descriptive and inferential statistic methods using $\mathrm{Z}$ test and Chi-square test with the help of software SPSS V.23.

Distribution of categorical data such as gender, age, duration of hours, and professionals was expressed as 


\begin{tabular}{|c|c|c|c|c|c|c|c|c|c|}
\hline \multirow[t]{2}{*}{ Physical symptoms } & \multirow[t]{2}{*}{ Responses } & \multicolumn{2}{|c|}{ Medicos } & \multicolumn{2}{|c|}{ Nurses } & \multicolumn{2}{|c|}{ Paramedicals } & \multicolumn{2}{|c|}{ Others } \\
\hline & & No. & $\%$ & No. & $\%$ & No. & $\%$ & No. & $\%$ \\
\hline \multirow{3}{*}{$\begin{array}{l}\text { While using PPE did you face difficulty in } \\
\text { moving around (restriction in movement)? }\end{array}$} & Very Difficult & 21 & 17 & 40 & 59 & 14 & 61 & 4 & 27 \\
\hline & Difficult & 89 & 74 & 18 & 26 & 4 & 17 & 10 & 67 \\
\hline & Not at all Difficult & 11 & 9 & 10 & 15 & 5 & 22 & 1 & 7 \\
\hline \multirow{3}{*}{ Have you faced difficulty in donning? } & Very Difficult & 2 & 2 & 22 & 32 & 6 & 26 & 7 & 47 \\
\hline & Difficult & 54 & 45 & 44 & 65 & 17 & 74 & 8 & 53 \\
\hline & Not at all Difficult & 65 & 54 & 2 & 3 & 0 & 0 & 0 & 0 \\
\hline \multirow{3}{*}{ Have you faced difficult in Doffing? } & Very Difficult & 14 & 12 & 33 & 49 & 11 & 48 & 1 & 7 \\
\hline & Difficult & 74 & 61 & 29 & 43 & 10 & 43 & 14 & 93 \\
\hline & Not at all Difficult & 33 & 27 & 6 & 9 & 2 & 9 & 0 & 0 \\
\hline \multirow{3}{*}{$\begin{array}{l}\text { While using PPE did you face difficulty in } \\
\text { communication? }\end{array}$} & Very Difficult & 50 & 41 & 41 & 60 & 15 & 65 & 2 & 13 \\
\hline & Difficult & 65 & 54 & 16 & 24 & 4 & 17 & 12 & 80 \\
\hline & Not at all Difficult & 6 & 5 & 11 & 16 & 4 & 17 & 1 & 7 \\
\hline \multirow{3}{*}{$\begin{array}{l}\text { While using PPE did you face difficulty in } \\
\text { hearing? }\end{array}$} & Very Difficult & 33 & 27 & 42 & 62 & 16 & 70 & 7 & 47 \\
\hline & Difficult & 75 & 62 & 20 & 29 & 6 & 26 & 8 & 53 \\
\hline & Not at all Difficult & 13 & 11 & 6 & 9 & 1 & 4 & 0 & 0 \\
\hline \multirow{3}{*}{$\begin{array}{l}\text { While using PPE did you face difficulty in } \\
\text { understanding surroundings? }\end{array}$} & Very Difficult & 23 & 19 & 42 & 62 & 12 & 52 & 3 & 20 \\
\hline & Difficult & 75 & 62 & 21 & 31 & 8 & 35 & 12 & 80 \\
\hline & Not at all Difficult & 23 & 19 & 5 & 7 & 3 & 13 & 0 & 0 \\
\hline \multirow{3}{*}{$\begin{array}{l}\text { While using PPE did you face difficulty in } \\
\text { seeing? }\end{array}$} & Very Difficult & 73 & 60 & 36 & 53 & 13 & 57 & 4 & 27 \\
\hline & Difficult & 47 & 39 & 16 & 24 & 2 & 9 & 10 & 67 \\
\hline & Not at all Difficult & 1 & & 16 & 24 & 2 & 9 & 1 & 7 \\
\hline
\end{tabular}

frequency and percentage. The qualitative data such as gender, age, duration of hours and professionals are associated with the parameters such as physical, physiological, and mental to know if there is any significant difference exists between the parameters with gender, age, duration of hours, and professional s using Chi-square test. To know the proportion of higher difference exists between different professional groups Z-test is used. All the statistical analysis was carried out at $5 \%$ level of significance and a $\mathrm{P}<0.05$ was considered as significant.

\section{RESULTS}

A total of 227 respondents were included in the study depicted in Figure 1.

This sample included 157 (69\%) males and 70 (31\%) females. Majority of the Health Care Professionals were in the age group of $21-30$ years $186(82 \%), 31(14 \%)$ were in $31-40$ years and only $10(4 \%)$ were in the age group $>41$ years and majority $124(54.6 \%)$ of the health care professionals used the PPE for 4-6 h, $84(37 \%)$ participants used for $>6 \mathrm{~h}$ and $19(8.4 \%)$ used for $<4 \mathrm{~h}$. Comorbidities suffered by health care professionals include Asthma 7 (3\%), hypertension 1 (0.44\%), Asthma 7 (3\%), allergies $22(10 \%)$, and majority of the health care workers 197 (87\%) didn't have any other medical co-morbidities.

Physical, physiological, and psychological health consequences faced by frontline warriors using PPE and their responses according to three-point Likert's scale, profession wise is shown in Tables 1-3, respectively.

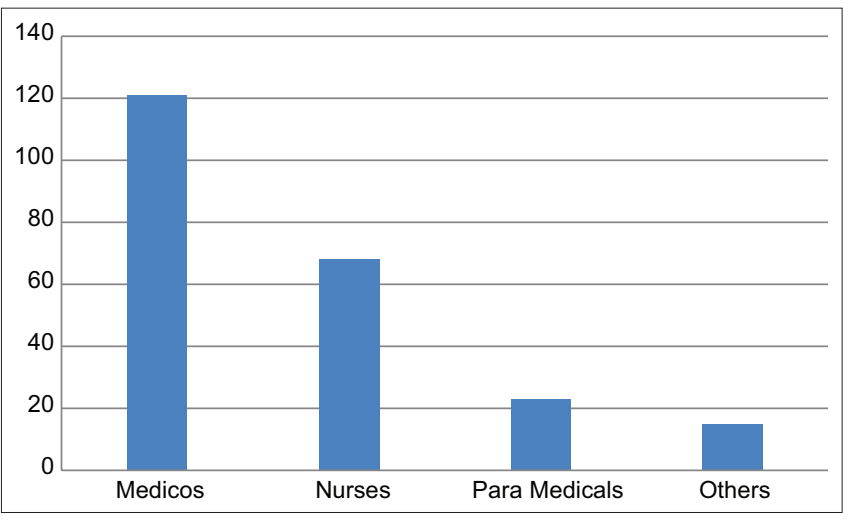

Figure 1: Distribution of study participants according to profession profession wise

A gender-wise association of health care professionals in physical, physiological, and psychological health consequences was not found to be statistically significant as (P-value was 0.312, 0.683, and 0.551).

An association between physical, physiological, and psychological health consequences with duration of PPE usage that is with less than $4 \mathrm{~h}, 4-6 \mathrm{~h}$ and more than $6 \mathrm{~h}$ was compared in all the professionals (Table 4), and it was found that there was no significant difference between Physical, physiological, and psychological in less than $4 \mathrm{~h}$ and $4-6 \mathrm{~h}$ duration. There is significant difference in less than $4 \mathrm{~h}$ and more than $6 \mathrm{~h}$ with only respect to psychological symptoms. Significant difference in all three health consequences with 4-6 h and more than $6 \mathrm{~h}$ was observed (Considering $\mathrm{P}<0.05$ as statistically significant). 
Table 2: Physiological symptoms faced by health care professionals

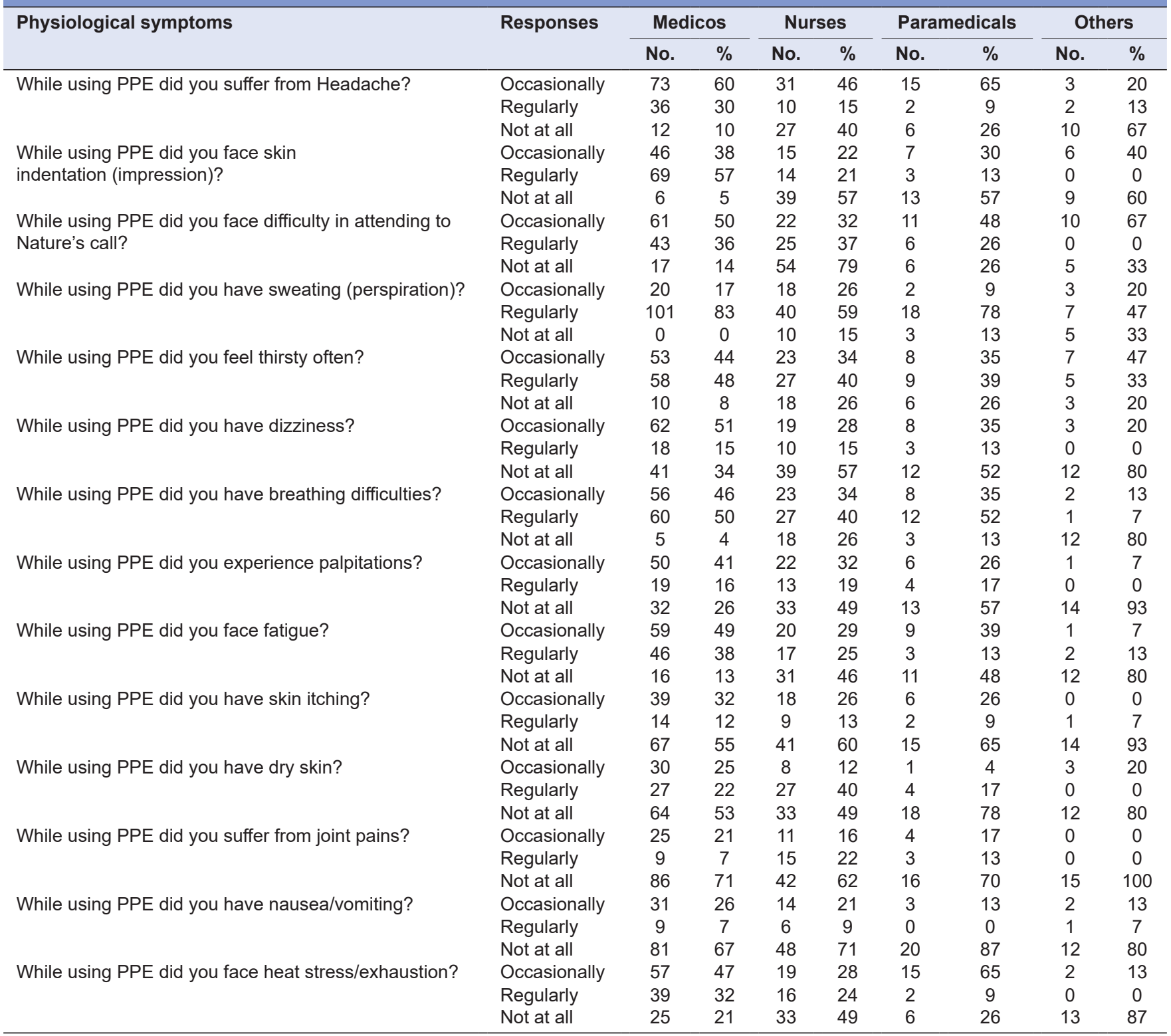

Table 3: Psychological symptoms faced by health care professionals

\begin{tabular}{|c|c|c|c|c|c|c|c|c|c|}
\hline \multirow[t]{2}{*}{ Psychological symptoms (50) } & \multirow[t]{2}{*}{ Responses } & \multicolumn{2}{|c|}{ Medicos } & \multicolumn{2}{|c|}{ Nurses } & \multicolumn{2}{|c|}{ Paramedicals } & \multicolumn{2}{|c|}{ Others } \\
\hline & & No. & $\%$ & No. & $\%$ & No. & $\%$ & No. & $\%$ \\
\hline \multirow[t]{3}{*}{ While using PPE did you feel restlessness? } & & 69 & 57 & 20 & 29 & 12 & 52 & 5 & 33 \\
\hline & Regularly & 38 & 31 & 25 & 37 & 5 & 22 & 0 & 0 \\
\hline & Not at all & 14 & 12 & 23 & 34 & 6 & 26 & 10 & 67 \\
\hline \multirow[t]{3}{*}{ While using PPE did you feel anxious? } & Occasionally & 74 & 61 & 24 & 35 & 14 & 61 & 3 & 20 \\
\hline & Regularly & 23 & 19 & 11 & 16 & 0 & 0 & 0 & 0 \\
\hline & Not at all & 24 & 20 & 33 & 49 & 9 & 39 & 12 & 80 \\
\hline \multirow[t]{3}{*}{ While using PPE did you face difficulty in making decisions? } & Occasionally & 59 & 49 & 17 & 25 & 5 & 22 & 1 & 7 \\
\hline & Regularly & 15 & 12 & 14 & 21 & 6 & 26 & 0 & 0 \\
\hline & Not at all & 47 & 39 & 37 & 54 & 12 & 52 & 14 & 93 \\
\hline \multirow[t]{3}{*}{ During COVID-19 duty time did you face sleeplessness? } & Occasionally & 41 & 34 & 15 & 22 & 10 & 43 & 1 & 7 \\
\hline & Regularly & 42 & 35 & 26 & 38 & 4 & 17 & 1 & 7 \\
\hline & Not at all & 38 & 31 & 27 & 40 & 9 & 39 & 13 & 87 \\
\hline \multirow{2}{*}{$\begin{array}{l}\text { During COVID-19 duty time did you have the fear of getting } \\
\text { infected/transferring infection to family members }\end{array}$} & Yes & 16 & 13 & 23 & 34 & 10 & 43 & 6 & 40 \\
\hline & No & 9 & 7 & 27 & 40 & 11 & 48 & 6 & 40 \\
\hline
\end{tabular}




\begin{tabular}{|c|c|c|c|c|c|}
\hline Parameters & Responses & Less than $4 \mathrm{~h}$ & 4-6 $h$ & Chi-square $(\mathrm{df}=2)$ & P-value \\
\hline \multirow[t]{3}{*}{ Physical } & Very Difficult & 3 & 31 & 0.89 & 0.641 \\
\hline & Difficult & 12 & 66 & & \\
\hline & Not at all Difficult & 4 & 27 & & \\
\hline \multirow[t]{3}{*}{ Physiological } & Occasionally & 8 & 47 & 0.296 & 0.863 \\
\hline & Regularly & 5 & 37 & & \\
\hline & Not at all & 5 & 40 & & \\
\hline \multirow[t]{3}{*}{ Psychological } & Very Difficult & 11 & 59 & 0.554 & 0.758 \\
\hline & Difficult & 5 & 31 & & \\
\hline & Not at all Difficult & 4 & 34 & & \\
\hline Parameters & Responses & Less than $4 \mathrm{~h}$ & More than $6 \mathrm{~h}$ & Chi-square $(d f=2)$ & P-*value \\
\hline \multirow[t]{3}{*}{ Physical } & Very Difficult & 3 & 9 & 2.05 & 0.36 \\
\hline & Difficult & 12 & 43 & & \\
\hline & Not at all Difficult & 4 & 32 & & \\
\hline \multirow[t]{3}{*}{ Physiological } & Occasionally & 8 & 22 & 3.18 & 0.204 \\
\hline & Regularly & 5 & 21 & & \\
\hline & Not at all & 5 & 41 & & \\
\hline \multirow[t]{3}{*}{ Psychological } & Very Difficult & 11 & 23 & 7.34 & 0.025 \\
\hline & Difficult & 5 & 18 & & \\
\hline & Not at all Difficult & 4 & 43 & & \\
\hline Parameters & Responses & $4-6 h$ & more than $6 \mathrm{~h}$ & Chi-square (df=2) & P-value \\
\hline \multirow[t]{3}{*}{ Physical } & Very Difficult & 31 & 9 & 10.1 & 0.007 \\
\hline & Difficult & 66 & 43 & & \\
\hline & Not at all Difficult & 27 & 32 & & \\
\hline \multirow[t]{3}{*}{ Physiological } & Occasionally & 47 & 22 & 6.01 & 0.049 \\
\hline & Regularly2 & 37 & 21 & & \\
\hline & Not at all & 40 & 41 & & \\
\hline \multirow[t]{3}{*}{ Psychological } & Very Difficult & 59 & 23 & 13.1 & 0.001 \\
\hline & Difficult & 31 & 18 & & \\
\hline & Not at all Difficult & 34 & 43 & & \\
\hline
\end{tabular}

Table 5 shows significant difference in physical, physiological, and psychological health consequences among medicos and nurses. Significant difference was observed among medicos and paramedical only in physiological and not in physical, psychological components, and there is significant difference between medicos and others with respect to physical and psychological and not in physiological component. There is higher chance of predicting for physical, Physiological, and psychological components between medicos and nurses and not in other professionals.

The proportion of medicos with parameters such as physical, physiological, and psychological health consequences is more than Nurses is tested using z-test for two population proportion. The value of $z$ is 2.7483 , 2.868 and 2.6105 and the $P$ value was found to be 0.00298, 0.00205 and 0.00453; hence, it is concluded that the medicos face more difficult in all three parameters comparing with nurses (Table 5).

Table 6 shows there is no significant difference between physical, physiological and psychological health consequences in different age groups, however significant difference was seen only in psychological symptoms in age group of $21-30$ years and $31-40$ years.

\section{DISCUSSION}

Global outbreak of deadly corona virus disease has forced health care professionals of various disciplines in Hospital and Community setting to use full Level III PPE which form a very important part of protective armour to avoid contamination from covid patients. However, there are various physical, psychological, and physiological consequences on health which can influence users functioning and performance associated with usage of PPE. ${ }^{8,9,12}$ Hence, this study was carried out to assess these health consequences faced by health care professionals using PPE treating the COVID-19 patients for timely and effective redresses. For better comparison, this study included all strata of health care professionals who used PPE.

Among the physical symptoms most of the study participants found it difficult in both donning (putting on) and doffing (removing of), restriction in movements and difficult in hearing and understanding the surroundings and very difficult in visual perception and communication.

Similar study was conducted in a Bi-national survey in Portuguese and Israel by Parush et al., the PPE equipment 
Table 5: Professional-wise association in physical, physiological, and psychological symptoms

\begin{tabular}{|c|c|c|c|c|c|}
\hline Parameters & Reponses & Medicos & Nurses & Chi-square $(\mathrm{df}=2)$ & P-value \\
\hline \multirow[t]{3}{*}{ Physical } & Very Difficult & 48 & 19 & 7.58 & 0.02 \\
\hline & Difficult & 40 & 17 & & \\
\hline & Not at all Difficult & 33 & 32 & & \\
\hline \multirow{3}{*}{ Physiological } & Occasionally & 30 & 37 & 16.7 & 0.0002 \\
\hline & Regularly & 69 & 24 & & \\
\hline & Not at all & 22 & 7 & & \\
\hline \multirow[t]{3}{*}{ Psychological } & Very Difficult & 61 & 19 & 10.1 & 0.006 \\
\hline & Difficult & 29 & 19 & & \\
\hline & Not at all Difficult & 31 & 30 & & \\
\hline Parameters & Reponses & Medicos & Para medicals & Chi-square $(\mathrm{df}=2)$ & P-value \\
\hline \multirow[t]{3}{*}{ Physical } & Very Difficult & 48 & 7 & 3.90 & 0.143 \\
\hline & Difficult & 40 & 5 & & \\
\hline & Not at all Difficult & 33 & 11 & & \\
\hline \multirow[t]{3}{*}{ Physiological } & Occasionally & 30 & 13 & 9.40 & 0.009 \\
\hline & Regularly & 69 & 7 & & \\
\hline & Not at all & 22 & 3 & & \\
\hline \multirow[t]{3}{*}{ Psychological } & Very Difficult & 61 & 10 & 1.82 & 0.402 \\
\hline & Difficult & 29 & 4 & & \\
\hline & Not at all Difficult & 31 & 9 & & \\
\hline Parameters & Reponses & Medicos & Others & Chi-square $(\mathrm{df}=2)$ & P-value \\
\hline \multirow[t]{3}{*}{ Physical } & Very Difficult & 48 & 3 & 9.61 & 0.008 \\
\hline & Difficult & 40 & 2 & & \\
\hline & Not at all Difficult & 33 & 10 & & \\
\hline \multirow[t]{3}{*}{ Physiological } & Occasionally & 30 & 4 & 3.35 & 0.18 \\
\hline & Regularly & 69 & 11 & & \\
\hline & Not at all & 22 & 0 & & \\
\hline \multirow[t]{3}{*}{ Psychological } & Very Difficult & 61 & 2 & 15.4 & 0.00045 \\
\hline & Difficult & 29 & 10 & & \\
\hline & Not at all Difficult & 31 & 13 & & \\
\hline
\end{tabular}

Table 6: Age-wise association in physical, physiological, and psychological symptoms

\begin{tabular}{|c|c|c|c|c|c|}
\hline Parameters & Reponses & $21-30$ years & $31-40$ years & Chi-square (df=2) & P-value \\
\hline \multirow[t]{3}{*}{ Physical } & Very Difficult & 70 & 13 & 1.81 & 0.404 \\
\hline & Difficult & 87 & 16 & & \\
\hline & Not at all Difficult & 29 & 2 & & \\
\hline \multirow[t]{3}{*}{ Physiological } & Occasionally & 64 & 9 & 4.68 & 0.096 \\
\hline & Regularly & 56 & 5 & & \\
\hline & Not at all & 66 & 17 & & \\
\hline \multirow[t]{3}{*}{ Psychological } & Very Difficult & 81 & 8 & 10.6 & 0.005 \\
\hline & Difficult & 47 & 4 & & \\
\hline & Not at all Difficult & 58 & 19 & & \\
\hline Parameters & Reponses & $21-30$ & $\geq 41$ & Chi-square $(\mathrm{df}=2)$ & P-value \\
\hline \multirow[t]{3}{*}{ Physical } & Very Difficult & 70 & 3 & 0.286 & 0.867 \\
\hline & Difficult & 87 & 5 & & \\
\hline & Not at all Difficult & 29 & 2 & & \\
\hline \multirow[t]{3}{*}{ Physiological } & Occasionally & 64 & 3 & 0.934 & 0.627 \\
\hline & Regularly & 56 & 2 & & \\
\hline & Not at all & 66 & 5 & & \\
\hline \multirow[t]{3}{*}{ Psychological } & Very Difficult & 81 & 4 & 0.366 & 0.833 \\
\hline & Difficult & 47 & 2 & & \\
\hline & Not at all Difficult & 58 & 4 & & \\
\hline Parameters & Reponses & $31-40$ & $\geq 41$ & Chi-square $(\mathrm{df}=2)$ & P-value \\
\hline \multirow[t]{3}{*}{ Physical } & Very Difficult & 13 & 3 & 1.7 & 0.427 \\
\hline & Difficult & 16 & 5 & & \\
\hline & Not at all Difficult & 2 & 2 & & \\
\hline \multirow[t]{3}{*}{ Physiological } & Occasionally & 9 & 3 & 0.102 & 0.95 \\
\hline & Regularly & 5 & 2 & & \\
\hline & Not at all & 17 & 5 & & \\
\hline \multirow[t]{3}{*}{ Psychological } & Very Difficult & 8 & 4 & 1.39 & 0.499 \\
\hline & Difficult & 4 & 2 & & \\
\hline & Not at all Difficult & 19 & 4 & & \\
\hline
\end{tabular}


usage amongst health care professionals was found to be associated with difficulties related to discomfort of wearing PPE, hearing, seeing and doffing were observed in $78 \%$, $50 \%, 89 \%$ and $44 \%$ of the study subjects respectively in Israel survey and $87 \%, 64 \%, 84 \%$ and $77 \%$ of study subjects, respectively, in a Portugal study. ${ }^{8}$

Difficulties faced while doffing and donning can be overcome by providing proper education to adhere to the protocol of doffing and donning and frequent practice to reduce the self-contamination. Other physicals symptoms can be minimized to some extent by manufacturing PPEs which are user friendly and at the same time protect them from contracting the Covid infection.

Among the physiological symptoms majority of the medicos, nurses and paramedicals regularly faced difficulty in breathing, sweating and felt thirsty whereas majority of other category participants did not have breathing difficulty but had difficulty in attending natures call. Occasionally majority of medicos faced palpitations, headache fatigue and heat exhaustion. Majority of the nurses not at all experienced most of physiological symptoms except breathing difficulty, sweating and thirsty. Even the majority of the paramedicals did not suffer most of physiological symptoms except breathing difficulty, sweating, felt thirsty and had heat exhaustion. Majority of the study participants of all the four categories did not suffer from either pressure or moist related skin injuries, joint pains, nausea/vomiting. It is interesting to know that more than $80 \%$ of the other category health care workers did not suffer from any physiological symptoms.

Similar to present study, in a North Indian study, conducted in all categories of health care workers, Agarwal et al., observed heat exhaustion (100\%) and breathlessness (61\%) in majority of the PPE users. ${ }^{13}$

In another North Indian study performed among Forensic team using PPE, five team members felt discomfort, excessively hot, enhanced perspiration, dyspnea, suffocation, dehydration, or facial redness. ${ }^{14}$

Similarly, Yuan et al., observed heat stress, respiratory difficulties, dizziness, nausea and varying degrees of facial skin indentation in their study participants. ${ }^{6} 94.57 \%$ of physiological adverse reactions were noticed in a study conducted by respiratory medicine department, China. ${ }^{6}$ Literature search did not find enough studies to compare the digestive symptoms during PPE usage.

Overheating due to PPE is the very common symptoms seen in all above studies including our study; PPE may cause an increase in body temperature by preventing heat loss by evaporation of the sweat. India being a tropical country with both hot and humid climate, heat exhaustion will be even more troublesome. In addition to prevent the spread of droplet infection shut down of central air-conditioning system further adds to the problem.

In contrast to this study, a study done by Foo et al., and Battista et al., observed high rates of adverse skin reactions like dry skin, acne, itch and rash to PPE. ${ }^{15,16}$ Yan et al., also found that health workers fighting against covid 19 are prone for skin and mucus membrane injury. ${ }^{17}$

In an American study by Rosner ${ }^{18}$ apart from the head ache, skin related issues like skin break down and acne was observed in majority of the health care workers.

In a meta-analysis carried out by Galanis et al., ${ }^{19}$ commonest physiological challenge faced was Headache, pressure and sweating related skin reactions and breathing discomfort.

The plausible solution to overcome the physiological symptoms suffered by the PPE users is by using effective reusable, water absorptive, customized PPE kits. Many health-related problems like obesity, respiratory diseases (Asthma, COPD) can exacerbate the physiological symptoms associated with PPE usage, this can be tackled by giving regular breaks and to report the symptoms related to PPE use.

Psychological status of the health care professionals was assessed, majority of paramedical felt restless and anxiousness occasionally but medicos faced sleeplessness regularly and felt anxiousness and restless occasionally. It was interesting to know that nurses did not have any of the psychological consequences. Majority of health care professionals didn't face difficulty in making decision during COVID-19 duty period and also were not sure whether they will get infected or not while taking care of COVID-19 sufferers. Similarly in an Indian study, it was found that the prevalence of anxiety, depression and distress in health care workers was $17.7 \%, 11.4 \%$ and $3.7 \%$ respectively. ${ }^{10}$

In a meta-analysis of Health care workers experienced high levels of depression, anxiety, insomnia, and distress. ${ }^{20-22}$ In contrast to present study, in the meta-analysis ${ }^{20,21}$ female nurses were disproportionately affected more from mental health consequences. The difference may be due to that the frontline female nurses work in close contact with patients for longer working hours and may be accustomed to the duty.

These psychological issues may be overcome by providing proper training, psychological support being in contact 
with the friends and family members through digital media, refraining from alcohol and smoking, psychological counseling.

Interestingly in present study, medicos experienced overall more symptoms and other category workers which mainly included attenders had less symptoms. The differences in the physical, physiological and psychological adverse events caused by PPE use among four different categories of health workers in this study may be due to comprehensive effect with sociodemographic, clinical job characteristics and associated health issues. However, these finding calls for further research to prepare better for the future pandemics.

This is the first study to best of our knowledge to uncover the various health effects which include physical, physiological and psychological consequences in the event of major public emergency. During an epidemic the infection of health care professionals will have major negative impact on capacity to treat patients on the morale of professionals and on public confidence because appropriate protection of health care professional is of utmost importance in response to COVID-19 in any health care system.

\section{CONCLUSION}

Medicos faced more difficulty and regularly in all the three health consequences comparing with nurses, paramedicals and least by the other category health care workers. This study provides awareness of various health consequences and difficulties experienced by the health care professionals while on PPE, training of health care professionals physically, mentally and emotionally improves their wellbeing, thus during PPE usage they can execute the patient care effectively and efficiently. This study also serves as a professional health advisory for other front-line healthcare professionals globally who are working to treat patients with COVID-19. Further studies may provide a guide to improve the design and utility of PPE so that it will ensure not only the safety but also the comfort and well-being of healthcare professionals during any of the future epidemics of this century.

\section{ACKNOWLEDGMENT}

Sincere thanks to all the frontline COVID-19 health care warriors of Rajarajeswari Medical College and Hospital, Bengaluru.

\section{REFERENCES}

1. Corona Virus Disease (COVID 2019) Situation Reports. Available from: https://www.who.int/emergencies/disease/ novel-coronavirus-2019/situation-reports [Last accessed on 2021 Apr 24].

2. Huang $Y$ and Zhao N. Generalized anxiety disorder, depressive symptoms and sleep quality during COVID-19 outbreak in China: A web-based cross-sectional survey. Psychiatry Res. 2020;288:112954.

http://dx.doi.org/10.1016/j.psychres.2020.112954

3. Team NCPERE. The epidemiological characteristics of an outbreak of 2019 novel coronavirus diseases (COVID-19) in China. Zhonghua Liuxingbingxue Zazhi. 2020;41(2):145-151. https://doi.org/10.3760/cma.j.issn.0254-6450.2020.02.003

4. Han $Y$ and Yang $H$, The transmission and diagnosis of 2019 novel coronavirus infection disease (COVID-19): A Chinese perspective. J Med Virol. 2020;92(6):639-644. https://doi.org/10.1002/jmv.25749

5. Honda $\mathrm{H}$ and Iwata K. Personal protective equipment and improving compliance among healthcare workers in high-risk settings. Curr Opin Infect Dis. 2016;29(4):400-406. https://doi.org/10.1097/qco.0000000000000280

6. Yuan N, Yang WX, Lu JL and Zhang-Hong LV. Investigation of adverse reactions in healthcare personnel working in Level 3 barrier protection PPE to treat COVID-19. Post Grad Med J. 2020;1:1-4.

http://dx.doi.org/10.1136/postgradmedj-2020-137854

7. Wilson W, Raj JP, Rao S, Ghiya M, Nedungalaparambil NM, Mundra $\mathrm{H}$, et al. Prevalence and predictors of stress, anxiety, and depression among healthcare workers managing COVID-19 pandemic in India: A nationwide observational study. Indian J Psychol Med. 2020;42(4):353-358. https://doi.org/10.1177\%2F0253717620933992

8. Parush A, Wacht O, Gomes R and Frenkel A. Human factor considerations in using personal protective equipment in the COVID-19 pandemic context: Binational survey study. J Med Internet Res. 2020;22(6):e19947.

https://doi.org/10.2196/19947

9. Zhang WR, Wang K, Yin L, Zhao WF, Xue Q, Peng M, et al. Mental Health and Psychosocial Problems of Medical Health Workers during the COVID-19 Epidemic in China. Psychother Psychosom. 2020;89(4):242-250. https://doi.org/10.1159/000507639

10. Spoorthy MS, Pratapa SK and Mahant S. Mental health problems faced by healthcare workers due to the COVID-19 pandemic a review. Asian J Psychiatr. 2020;51:102119. https://dx.doi.org/10.1016\%2Fj.ajp.2020.102119

11. World Health Organization. Rational use of personal protective equipment for COVID-19 and considerations during severe shortages: interim guidance, $23^{\text {th }}$ December; 2020. Available from: https://apps.who.int/iris/handle/10665/338033

12. Person E, Lemercier C, Royer A and Reychler G. Effect of a surgical mask on six minute walking distance. Rev Mal Respir. 2018;35(3):264-268.

https://doi.org/10.1016/j.rmr.2017.01.010

13. Agarwal A, Agarwal $S$ and Motiani P. Difficulties encountered while using PPE kits and how to overcome them: An Indian perspective. Cureus. 2020;12(11):e11652. https://dx.doi.org/10.7759\%2Fcureus. 11652

14. Vidua RK, Vivek K Chouksey VK, Daideepya C, Bhargava DC and Kumar J. Problems arising from PPE when worn for long periods. Med Legal J. 2020;88(Suppl 1):47-49. http://dx.doi.org/10.1177/0025817220935880

15. Foo CC, Goon AT, Leow YH and Goh CL. Adverse skin reactions to personal protective equipment against severe acute 
respiratory syndrome-a descriptive study in Singapore. Contact Dermatitis. 2006;55(5):291-294.

http://dx.doi.org/10.1111/j.1600-0536.2006.00953.x

16. Battista RA, Ferraro M, Piccioni LO, Alzanni GE and Bussi M. Personal protective equipment (PPE) in COVID 19 pandemic related symptoms and adverse reactions in healthcare workers and general population. Am Coll Occup Environ Med. 2021;63(2):e81-e85.

https://dx.doi.org/10.1097\%2FJOM.0000000000002100

17. Yan $Y$, Chen $H$, Chen L, Cheng B, Diao P, Dong L, et al. Consensus of Chinese experts on protection of skin and mucous membrane barrier for healthcare workers fighting against coronavirus disease 2019. Dermatol Ther. 2020;33(4):e13310. https://dx.doi.org/10.1111\%2Fdth.13310

18. Rosner E. Adverse effects of pronlonged mask use among healthcare professionals during COVID-19. J Infect Dis Epidemiol. 2020;6(3):1-5.

https://doi.org/10.23937/2474-3658/1510130

19. Galanis P, Vraka I, Fragkou D, Bilali A and Kaitelidou D.
Impact of personal protective equipment use on health care workers' physical health during the COVID-19 pandemic: A systematic review and meta-analysis. Am J Infect Control. 2021;49(10):1305-1315

http://dx.doi.org/10.1101/2021.02.03.21251056

20. Wang J, Liu F, Tan JB, Harbarth S, Pittet D and Zingg W. Implementation of infection prevention and control in acute care hospitals in Mainland China a systematic review. Antimicrob Resist Infect Control. 2019;8:32.

https://doi.org/10.1186/s13756-019-0481-y

21. Shaukat N, Ali DM and Razzak J. Physical and mental health impacts of COVID-19 on healthcare workers: A scoping review. Int J Emerg Med. 2020;13(1):40.

https://doi.org/10.1186/s12245-020-00299-5

22. Vizheh M, Qorbani M, Arzaghi SM, Muhidin S, Javanmard Z and Esmaeili $M$. The mental health of healthcare workers in the COVID-19 pandemic: A systematic review. J Diabetes Metab Disord. 2020;19(2):1967-1978. http://dx.doi.org/10.1007/s40200-020-00643-9

\section{Authors Contribution:}

BCM - Concept and design of the study, prepared first draft of manuscript; RR- Concept, co-ordination, preparation of manuscript and revision of the manuscript SAC- Concept, statistical analysis and interpretation VG - Concept, reviewed the literature and manuscript preparation; CC - Interpreted the results, Statistical analysi; USMR - Design of the study \& reviewed the literature

\section{Work attributed to:}

Rajarajeswari Medical College and Hospital, Bengaluru - 560 078, Karnataka, India

Orcid ID:

Dr. Bindu CM - (i) https://orcid.org/0000-0003-1160-0899

Dr. Reena R - (i) https://orcid.org/0000-0003-0646-3877

Dr. Shyam AC - io https://orcid.org/0000-0001-5818-5122

Dr. Vivek G - https://orcid.org/0000-0002-3644-3765

Mrs. Chandrakala C - (D https://orcid .org/0000-0002-7115-8564

Dr. Usha SMR - (1) https://orcid.org/0000-0001-6118-194X

Source of Support: None, Conflict of Interest: None. 